Portland State University

PDXScholar

Sociology Faculty Publications and

Presentations

Sociology

$1-4-2013$

\title{
Tensions Between Firm Size and Sustainability Goals: Fair Trade Coffee in the United States
}

Philip H. Howard

Michigan State University

Daniel Jaffee

Portland State University, jaffee@pdx.edu

Follow this and additional works at: https://pdxscholar.library.pdx.edu/soc_fac

Part of the Place and Environment Commons, and the Politics and Social Change Commons Let us know how access to this document benefits you.

Citation Details

Howard, P. H., \& Jaffee, D. (2013). Tensions Between Firm Size and Sustainability Goals: Fair Trade Coffee in the United States. Sustainability (2071-1050), 5(1), 72-89. doi:10.3390/su5010072

This Article is brought to you for free and open access. It has been accepted for inclusion in Sociology Faculty Publications and Presentations by an authorized administrator of PDXScholar. Please contact us if we can make this document more accessible: pdxscholar@pdx.edu. 
Article

\title{
Tensions Between Firm Size and Sustainability Goals: Fair Trade Coffee in the United States
}

\section{Philip H. Howard ${ }^{1, *}$ and Daniel Jaffee ${ }^{2}$}

1 Department of Community, Agriculture, Recreation and Resource Studies, Michigan State University, 480 Wilson RD, Rm. 316, East Lansing, MI 48824, USA

2 Department of Sociology, Washington State University, 14204 NE Salmon Creek Avenue, Vancouver, WA 98686, USA; E-Mail: jaffee@wsu.edu

* Author to whom correspondence should be addressed; E-Mail: howardp@ msu.edu; Tel.: +1-517-355-8431; Fax: +1-517-353-8994.

Received: 5 November 2012; in revised form: 12 December 2012 / Accepted: 20 December 2012 / Published: 4 January 2013

\begin{abstract}
Sustainability marketing trends have typically been led by smaller, more mission-driven firms, but are increasingly attracting larger, more profit-driven firms. Studying the strategies of firms that are moving away from these two poles (i.e., mission-driven but larger firms, and profit-driven firms that are more committed to sustainability) may help us to better understand the potential to resolve tensions between firm size and sustainability goals. We used this approach to analyze a case study of the U.S. fair trade coffee industry, employing the methods of data visualization and media content analysis. We identified three firms that account for the highest proportion of U.S. fair trade coffee purchases (Equal Exchange, Green Mountain Coffee Roasters and Starbucks) and analyzed their strategies, including reactions to recent changes in U.S. fair trade standards. We found an inverse relationship between firm size and demonstrated commitment to sustainability ideals, and the two larger firms were much less likely to acknowledge conflicts between size and sustainability in their public discourse. We conclude that similar efforts to increase sustainability marketing for other products and services should be more skeptical of approaches that rely on primarily on the participation of large, profit-driven firms.
\end{abstract}

Keywords: firm size; Fair Trade; coffee; corporations; certification 


\section{Introduction}

Addressing sustainability goals has proven to be a successful marketing strategy for firms, both to gain market share and to increase profitability [1]. The wide success of third-party certified ecolabels, such as fair trade and organic, as well as first party sustainability claims, has encouraged more firms, and an increasing number of industries, to develop such efforts [2,3]. These trends have typically been initiated by what Hockerts and Wüstenhagen term "emerging Davids," or smaller, mission-driven firms, but are increasingly attracting "greening Goliaths," or larger, more profit-driven firms [4]. The latter may have less commitment to sustainability ideals (environmental, economic and social), as there are inherent tensions between the missions of firms that are already large (relative to competitors in the industry) and the goal of addressing the industry's negative social and environmental externalities that initially motivated the entry of mission-driven firms [4-6].

Not all companies, however, fall neatly into the ideal types of smaller, more committed firms and larger, less committed firms. Most studies have focused on these two categories, without examining large firms that are more committed than typical, or firms with high sustainability commitments that are larger than typical [7-9]. Studying the strategies of these businesses can provide a better understanding of the tensions between firm size and sustainability goals, as well as inform efforts to (a) increase the sustainability commitments of large firms, and to (b) assist small firms to scale up while maintaining high commitments to sustainability [4].

We explore these issues through a case study of firms in the U.S. fair trade coffee market using methods of data visualization and content analysis of media coverage. The fair trade market utilizes third-party certification to signify products that meet multiple (social, economic and environmental) sustainability criteria. This case is particularly interesting because of controversial recent policy changes by the entity that was until recently the sole fair trade certifier in the United States. In September 2011 Fair Trade USA (FTUSA, formerly Transfair USA) announced that it was resigning from the international fair trade certification body, Fair Trade International (FTI), and that it would begin certifying coffee produced on plantations, rather than only coffee from small farmer cooperatives, as stipulated by FTI standards. This decision has generated strong disagreements among U.S.-based coffee firms regarding the direction the fair trade system should take. These debates have become increasingly public over the past year [10-14], and have rendered these firms' strategic differences more visible than they were previously.

Below we review literature related to firm size and sustainability efforts, as well as studies that address these issues for fair trade specifically. We then describe how we approached the following two questions, and our findings for each:

- How is the U.S. fair trade coffee industry structured with respect to firm size and degree of engagement with fair trade?

- How have the firms with the highest volumes of fair trade purchases responded to tensions between size and sustainability goals?

The subsequent section discusses our research findings. Starbucks, Green Mountain Coffee Roasters and Equal Exchange were the three firms with the highest volumes of fair trade coffee purchases in the U.S. in recent years, and are therefore arguably contributing substantially to achieving 
both social and environmental sustainability goals in the fair trade coffee market. However, these three firms are also taking quite divergent paths, as reflected in the levels of fair trade certified coffee purchases relative to their overall coffee volumes, as well as their responses to the changing U.S. fair trade standards. We conclude that among these firms there is an inverse relationship between size and commitment to sustainability practices. In addition, the larger, more profit-driven firms are much less likely to acknowledge tensions between size and sustainability in their public discourse.

\section{Firm Size and Sustainability Goals}

The positive impacts of large firms participating in sustainability efforts may include (a) an increasing proportion of industry activities that meet sustainability criteria [6,15], (b) an increased availability of products and services for consumers that meet these criteria [16], and/or (c) a greater level of resources devoted to raising consumer awareness of sustainability goals [17]. There are also potential negative impacts, including tendencies for large firms that do participate in sustainability efforts to (a) only apply those practices to a very small percentage of their purchases or sales, while reaping benefits of positive publicity, (e.g., "greenwashing" or "fairwashing") $[15,18-20]$ and/or (b) attempt to weaken the original sustainability goals on an industry-wide basis in order to increase profits [9,21].

Conversely, small firms that develop sustainability innovations may have little influence on the industry as a whole unless these innovations spread to larger firms (typically the faster approach), or are scaled up to include a larger proportion of industry practices (typically the slower approach) [4]. This scaling up may involve the growth of small firms into much larger firms, or alternatively, the successful entrance of numerous other small, mission-driven firms into the industry. In any case, such dramatic departures from the status quo require negotiating tensions between the scale of the current market and the institutionalization of more socially and environmentally sustainable practices.

\subsection{Tensions}

These size/sustainability tensions have been described in relation to concepts in the economics and business literatures that include externalities, supply chain management, and innovation. Negative externalities are a form of market failure that allow the privatization of profits and the socialization of costs or harms, with the classic example being pollution from manufacturing industries [22]. Moving towards genuine sustainability requires firms and industries to internalize costs that were previously borne by society or the natural environment. Larger firms may find it more difficult to voluntarily reduce their externalities because they have greater investments in practices that shift these costs outside of the firm [4]. Importantly, this includes the shaping of consumer demand so that it is congruent with the continued profitability of big business [23]. Sustainability marketing at this scale therefore requires the expensive and difficult task of reshaping this demand for the mass market, not merely a small niche of consumers [6]. This presents a more significant barrier for small firms attempting to expand their market, because they typically lack the resources to market and advertise to such a broad extent.

Sustainability efforts also frequently require developing new supply chains to source more socially or environmentally sustainable inputs, which can be more difficult for larger firms that deal in high volumes [24]. One issue may simply be a lack of adequate supply of such inputs, while another may be 
that obtaining these inputs involves high transaction and search costs, as dealing with a large number of suppliers (or customers) is more costly in terms of time and resources than dealing with a smaller number [25]. Firms have an economic incentive to reduce the number of transactions, but the larger the firm relative to the scale of suppliers, the more difficult this becomes. Smaller firms encounter challenges at the distribution end of the supply chain when attempting to scale up, if they are not large enough to overcome these issues for large distributors or retailers [26-28].

Sustainability marketing can be viewed as a particular kind of innovation: there is a sizeable literature that suggests larger firms are typically more resistant to innovation, particularly when it involves more than merely small, incremental changes [4,6,29]. However, not all studies suggest inherent tensions between increased size and sustainability innovations. Many note that economies of scale or greater resources can make it easier for larger firms to adopt certain types of practices, such as using more sustainable technologies or requiring their suppliers to conform to sustainability standards, especially in industries that are capital intensive or highly concentrated [30-32].

\subsection{Tensions in Fair Trade}

Fair trade is a certification system that addresses multiple sustainability goals for primarily agricultural (but also non-food) products, largely produced in the global South. The key criteria underlying fair trade certification include minimum or base prices for producers (or working conditions for waged laborers), an added development premium, pre-harvest financing, and environmentally sustainable production practices, among others [19]. Fair trade is the primary product certification that emphasizes the social conditions of production, and thus places more emphasis on socioeconomic sustainability than other ecolabels, such as organic. Fair trade has achieved tremendous market success, surpassing \$6 billion in global sales in 2011 with double-digit growth rates being sustained for more than a decade $[33,34]$. Studies suggest that this label enhances consumers' positive perceptions of products, although willingness to pay a price premium is currently limited to a smaller subset of these consumers [35-37].

Tensions between firm size and sustainability have been illuminated by ongoing controversies over changing fair trade standards, and the increased certification of plantation products and waged labor in the fair trade system. The moves since 2005 by the global fair trade certifier Fair Trade International to actively expand the role of plantations for many crops including tea, fruit, spices, cut flowers, and other products (but not coffee, cocoa, honey or cotton) have unleashed heated debate about the movement's historical commitment to small farmers and smallholder production [38]. A key concern is that the economic advantages of plantations will undercut the small-scale producers who had long been excluded from conventional markets, a context that motivated the creation of the fair trade system orginally [39]. Some researchers have reported negative impacts of including plantations in the fair trade system, including that it undermines stronger state regulation of labor conditions [40], and that in practice it fails to reach the most disadvantaged plantations and their laborers because it privileges higher quality products, which are typically sourced from plantations with better off workers [41]. A study of plantation cut flowers in Ecuador, however, found that fair trade plantations had better outcomes for environmental (e.g., reduced pesticide use) and social (e.g. funding for community programs) issues when compared to other plantations [42]. 
For coffee, plantations may also cause greater negative environmental impacts than smallholder plots, as the former tend to have lower levels of shade tree cover (and thus less biodiversity) and higher use of agrochemicals $[43,44]$. Increased incomes from fair trade have also provided incentives for smallholders to maintain high levels of shade, increase tree biodiversity, and adopt more ecologically sustainable farming practices, such as composting and planting nitrogen-fixing cover crops $[19,45]$. These practices are frequently transferred to subsistence food plots as well [19].

One example of the tensions between different firm types in the realm of standards involves the criterion requiring that affordable financing (of $60 \%$ of the total contract price) be made available to farmer organizations in advance of the harvest, to avoid the classic "debt trap" plaguing small farmers worldwide. This requirement, however, is not honored consistently by firms purchasing fair trade certified coffee. Raynolds reported that profit-driven firms rarely provide advance financing for coffee contracts, while mission-driven firms consistently pre-finance [46]. Another area often honored in the breach is fair trade's stipulation of long-term trading relationships. Raynolds also found that larger, profit-driven firms prefer to enter mainly into one-year (or shorter) contracts with fair trade producer groups, rather than form stable relationships with suppliers as the mission-driven firms do consistently $[42,46]$.

While tensions between size and sustainability goals have been explored for some specific cases in the fair trade system, as described above, there has been insufficient research focusing on the firms making the largest contributions to the industry. To address this gap in the literature we focused on fair trade coffee in the U.S. Our first objective was to characterize the structure of this industry with respect to the size of the firms making fair trade purchases and their degree of engagement with fair trade. Our second objective was to analyze how the firms with the highest volumes of fair trade purchases have responded to tensions between size and sustainability goals, with a focus on recent standards changes.

\section{How is the U.S. Fair Trade Coffee Industry Structured with Respect to Firm Size and Engagement with Fair Trade?}

\subsection{Methods}

To characterize the structure of the U.S. fair trade coffee industry, we first collected data on firms' total purchases of green (unroasted) coffee, and their purchases of fair trade certified green coffee. The data were compiled from multiple sources, including corporate social responsibility reports; reports by NGOs, academic institutions, and industry; firms' responses to email inquiries; and media reports. While we were not able to obtain data for every firm in the industry, as many choose to keep such data confidential, all of the largest firms in the fair trade market, as well as a sample of smaller roasters, are represented. We constructed several visualizations to aid in data analysis. Compared to text-based formats, this approach permits the communication of large amounts of information more quickly, and with fewer burdens on short-term memory [47,48]. Figure 1 establishes the global context, while the remaining figures explore the U.S. fair trade coffee market in more depth. In Figure 1, proportional circles represent the volume of the total green coffee purchases of the top ten world coffee roasters. This graphic also uses proportional circles to represent the percentage and volume of fair trade certified purchases. 
Figure 1. Top Ten World Coffee Roasters: Fair Trade Certified and Non-Fair Trade Purchases, 2008 [49].

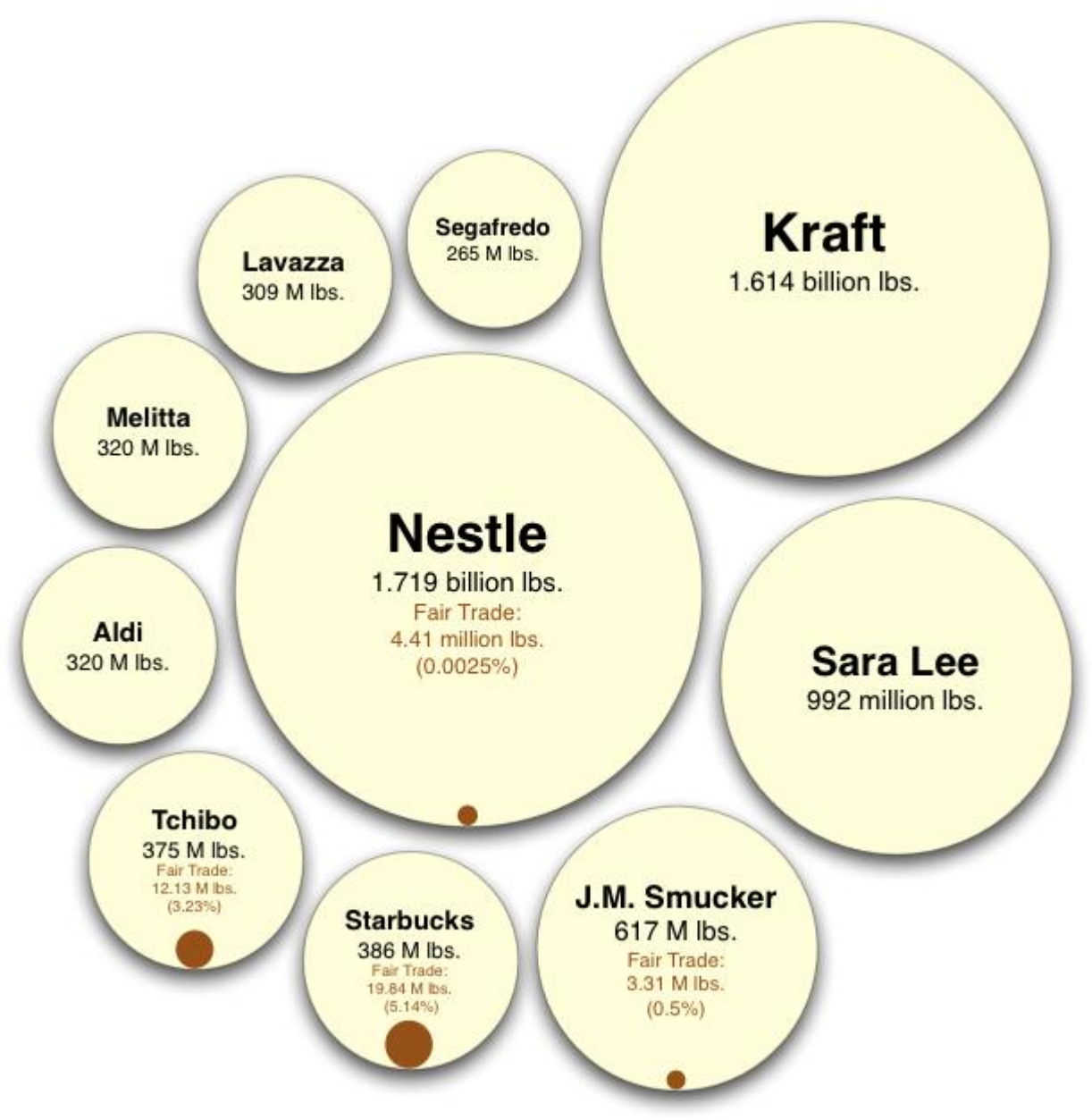

Figure 2 is a multi-variable plot of selected firms engaged in fair trade purchases in the United States. We plotted year of entry into fair trade on the $\mathrm{x}$ axis, fair trade as a percentage of total volume on the y axis, and fair trade volume in the year 2010 as proportional circles. Based on this figure we selected three U.S. firms that accounted for the largest volume of fair trade purchases, while representing both mission-driven (early entry; higher percentage of fair trade) and profit-driven (later entry; lower percentage of fair trade) firms. We then compiled additional information from company websites and scholarly literature to contextualize these firms, and to inform an additional graphic (Figure 3) illustrating the brands that are either owned by, or involved in roasting and/or marketing associations with these firms. 
Figure 2. Plot of Fair Trade Variables for Selected Coffee Firms in the United States: Year of Entry, Volume, and Percentage of Total Volume [49-52].

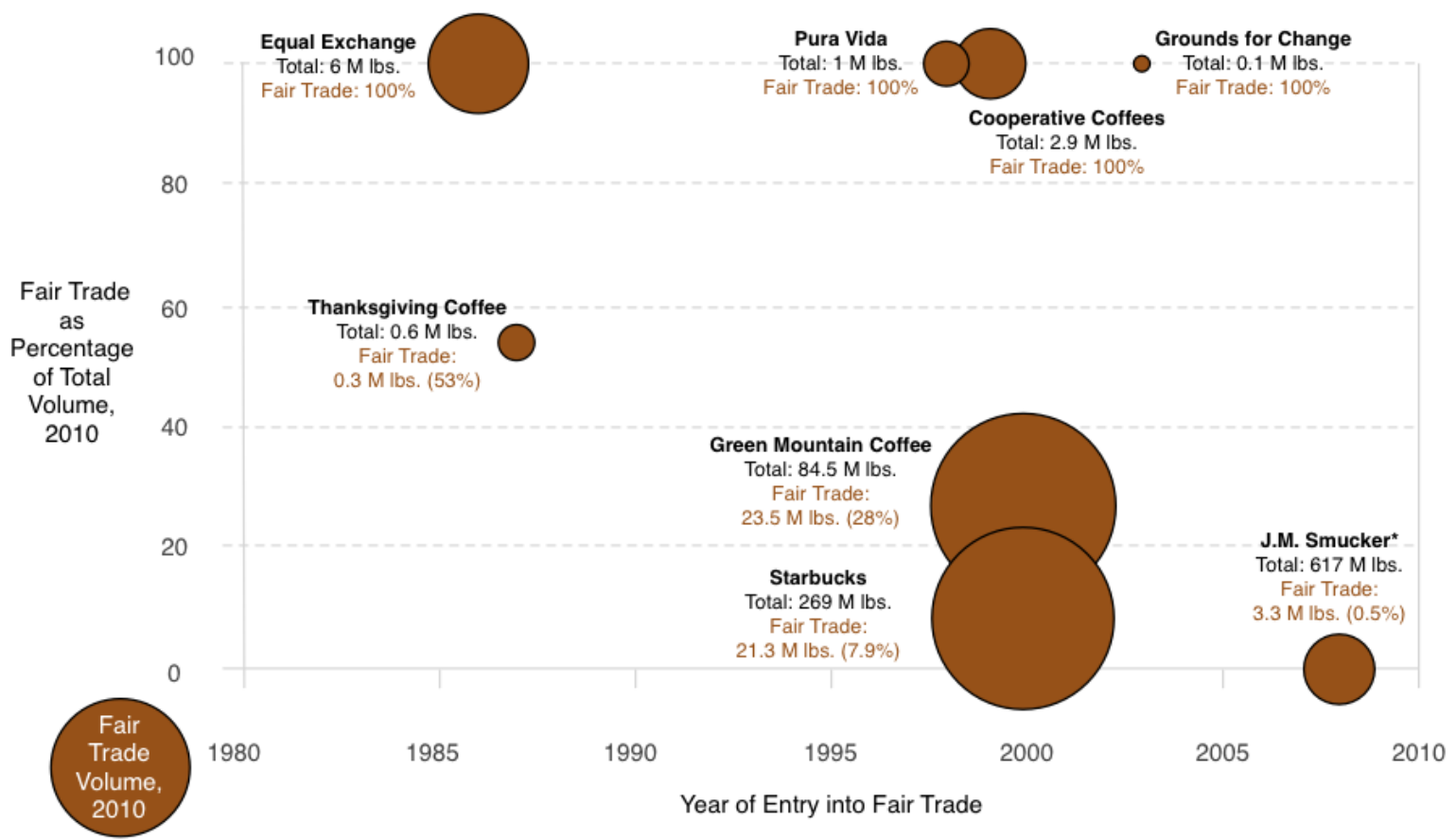

Figure 3. Brands and Connections for Firms Accounting for the Highest Proportion of Fair Trade Purchases.

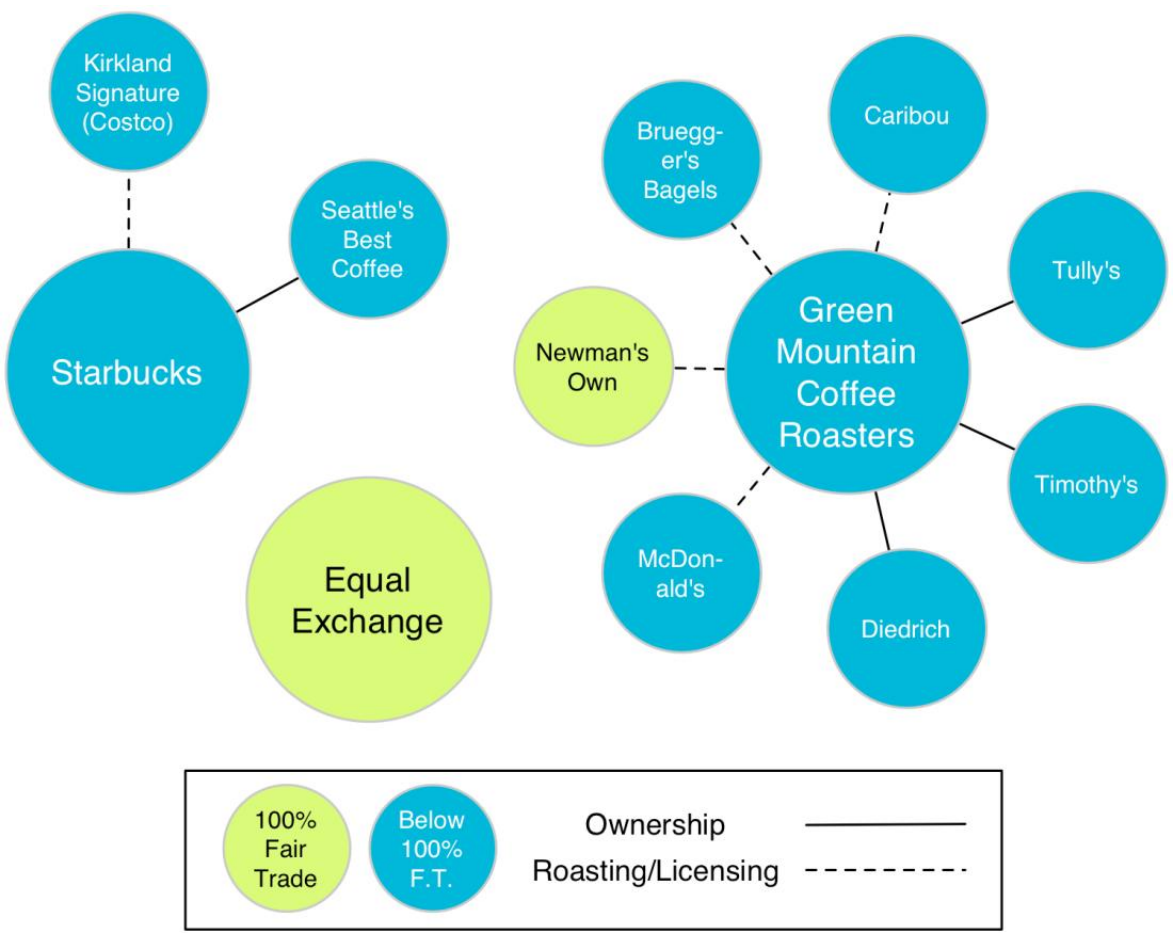




\subsection{Results}

\subsubsection{The Global Context}

Figure 1 depicts the overall context of non-fair trade and fair trade coffee purchases among the top ten firms internationally in 2008. It shows that only four of the ten purchased any fair trade certified coffee. These data suggest an inverse relationship between firm size and commitment to fair trade for those who choose to participate. Fifth-ranked Starbucks (U.S.) was the world's largest purchaser of fair trade certified coffee at this time (nearly 20 million pounds, or 5 percent of its total supply). Sixth-ranked Tchibo (Japan) had a slightly lower commitment to fair trade both by volume and percentage (approximately 12 million pounds; 3 percent of total volume), but this was significantly more than the two largest firms. For no. 1 Nestlé (Switzerland) and no. 4 J.M. Smucker (U.S.), fair trade purchases were relatively similar by volume (approximately 4 and 3 million pounds, respectively), but Nestle had by far the lowest percentage of fair trade purchases ( 0.0025 percent).

\subsubsection{The U.S. Context}

Figure 2 depicts the context in the United States for selected firms that purchased and sold fair trade certified coffee, as of 2010, on three dimensions: year of entry into fair trade certification, volume of fair trade purchases, and the percentage of total volume those fair trade purchases represent. Earlier entrants are on the left side of the graphic and later entrants are on the right side. Firms that purchase $100 \%$ fair trade coffee are at the top and firms with the lowest percentage of fair trade relative to total purchases are at the bottom. The later entrants with lower percentages of fair trade purchases are all large, publicly traded corporations (Green Mountain Coffee Roasters, Starbucks and J.M. Smucker), and the early entrants are smaller firms with much higher percentages of fair trade purchases. Thanksgiving Coffee is somewhat of an anomaly because although an earlier entrant, it does not purchase exclusively fair trade coffee. The remaining smaller firms shown are also all at the $100 \%$ level, despite entering the fair trade system in later years.

The firms of greatest interest with respect to our research objectives, however, are those that are making disproportionate contributions to sustainability goals through greater volumes of fair trade purchases (represented by the largest circles in the graphic). In this case Equal Exchange is purchasing more fair trade coffee than other highly committed firms, approximately twice as much as the next largest $100 \%$ fair trade firm, Cooperative Coffees (which is a cooperative composed of 23 smaller firms that purchase collectively). At the other end of the spectrum, Green Mountain Coffee Roasters (GMCR) and Starbucks are the two largest buyers of fair trade coffee beans in the U.S. (together accounting for more than $40 \%$ of the total volume certified by Fair Trade USA), despite their lower percentages of fair trade relative to total volume [34]. GMCR's fair trade certified purchases in 2010 totaled 23.5 million pounds, which was more than three times as large as Equal Exchange's fair trade purchases, and slightly more than Starbucks' 21 million pounds. GMCR's percentage of fair trade purchases was $27.8 \%$, while Starbucks' percentage was $7.9 \%$. Starbucks' much greater marketing emphasis on its first party (i.e., self-certified) Coffee and Farmer Equity (C.A.F.E.) Practices program, and its low percentage of fair trade purchases, have been characterized by some critics as “dabbling”[7]. Nevertheless, Starbucks was the world's largest buyer of fair trade coffee until 2010, 
and its size gave the firm a strong voice in the policy direction of fair trade in the U.S., as we discuss further below.

\subsubsection{Characteristics of Firms with Highest Proportion of Fair Trade Purchases}

Equal Exchange was the first fair trade coffee company in the U.S., established in 1986. It is organized as a worker-owned cooperative, and purchases coffee from small farmer cooperatives. Its legal structure is unique: if the company is sold, the proceeds must go to another fair trade organization, not to the worker-owners. It is located in West Bridgewater, Massachusetts. Equal Exchange focused exclusively on coffee in its early years, but has since expanded to chocolate, tea, bananas and other products. The firm reported $\$ 46.8$ million in annual revenue in 2011. Like other $100 \%$ fair trade firms, Equal Exchange's marketing efforts are focused primarily on the social responsibility dimension, while the two firms discussed below place far greater emphasis on the dimension of taste [53].

Green Mountain Coffee Roasters originated as a café, but became a publicly traded corporation in 1993. It is headquartered in Waterbury, Vermont. Like the other two firms, GMCR is a specialty coffee roaster, meaning that it focuses on higher quality Arabica coffee varieties that are differentiated from lower-cost, mass-market coffee. The firm began selling fair trade coffee in 2000 after being approached by Transfair USA (now FTUSA), and expanded these sales through a licensing agreement with Newman's Own Organics, a 100\% fair trade brand, in 2003 [54]. GMCR also uses other ecolabels, including organic and Rainforest Alliance certifications. The firm reported $\$ 2.6$ billion in annual revenue in 2011, and has grown very rapidly in recent years due to the popularity of the Keurig single-cup brewing machine (GMCR fully acquired Keurig in 2006) and its patented coffee pods that are inserted in the machine.

Starbucks is the largest coffeehouse chain in the world, and the largest specialty coffee firm. Like GMCR, it is a publicly traded corporation. It is based in Seattle, Washington. The firm began selling fair trade coffee in 2000 as a result of pressure from activist organizations, including Global Exchange, but has received frequent criticism since then for its relatively low percentage of fair trade purchases relative to total volume [19]. The firm reported \$11.7 billion in annual revenue in 2011.

Figure 3 depicts the other brands that have connections to these three firms. Starbucks owns Seattle's Best Coffee, and also roasts for the warehouse club Costco's private label brand, Kirkland Signature. Green Mountain Coffee Roasters owns the brands Tully's, Timothy's and Diedrich. In addition the company roasts for McDonald's, Bruegger's Bagels and Caribou Coffee, as well as the $100 \%$ fair trade brand Newman's Own. Equal Exchange does not have any subsidiary brands or roasting/licensing arrangements in the U.S., but does have joint branding alliances in other countries [55].

\section{How Have The Largest U.S. Fair Trade Coffee Firms Responded to Size/Sustainability Tensions?}

\subsection{Methods}

To characterize the responses of Starbucks, Green Mountain Coffee Roasters and Equal Exchange with respect to sustainability goals and tensions with firm size, we took two approaches. We first 
visualized and analyzed coffee purchasing behaviors since 2004, to more closely examine firms' levels of commitment over time. Second, we conducted a content analysis of firm responses and the public discourse surrounding Fair Trade USA's exit from the international certification system, which was announced in 2011.

As in the previous section, we collected data for fair trade volume and fair trade coffee as a percentage of total volume from the firms' annual reports, corporate social responsibility (CSR) reports and responses to email queries, as well as company websites. We constructed graphics to depict purchases for each firm from 2004 to 2011 and to compare these over time. Time is plotted on the $\mathrm{x}$ axis and volume (total and fair trade certified) on the y axis.

To analyze the discourse of recent changes in the U.S. fair trade system we conducted a search of the LexisNexis news database using the keywords "Fair Trade USA" for All News (English) from September 15, 2011 (the date of Fair Trade USA's announcement of its departure from the FTI system) to October 5, 2012. This resulted in 204 documents, including newspaper articles, press releases, web blogs, and TV/radio transcripts. This number was reduced to 153 after removing 51 duplicates (i.e., the same article reprinted in multiple outlets). We also searched firm blogs with same search term, resulting in additional 14 documents from Equal Exchange, three documents from GMCR and none from Starbucks. Finally, we included two additional documents from alternative media sources that were referenced by these firms' blogs for a total sample size of 172 . We conducted a content analysis of these documents, and our iterative coding process focused on the framing of issues related to firm size and sustainability standards.

\subsection{Results}

\subsubsection{Commitment to Fair Trade Volume and Percentage of Total Volume}

Figure 4 depicts the commitment of each of the three firms to fair trade purchases during the period 2004 to 2011. It shows both total green coffee purchases and fair trade purchases for each firm, thereby illustrating the percentage of fair trade volume relative to total volume in recent years. Figure 4a shows that Starbucks has fluctuated in its commitment to fair trade: after a gradual initial increase, its fair trade purchases leveled off from 2006 to 2008, then approximately doubled in 2009 to reach $10.6 \%$ of sales, but have fallen to approximately $8 \%$ in the last two years. Green Mountain Coffee Roasters, in contrast, has steadily increased its volume of Fair trade purchases, as seen in Figure 4b, although in the last two years the percentage of fair trade purchases has declined as its total coffee purchases grew dramatically. Since 2010, GMCR has been the world's largest purchaser of fair trade certified coffee, despite purchasing less than half as much total coffee as Starbucks. Figure $4 \mathrm{~b}$ indicates Equal Exchange's fair trade purchases were larger than GMCR in 2004 and 2005, although currently its total fair trade purchases are much less than the other two firms. Equal Exchange has maintained its commitment to $100 \%$ fair trade over this period, and its coffee purchases increased steadily from 2004 to 2009 , although they have leveled off since then. 
Figure 4. Total and Fair Trade Certified Coffee Purchases by Selected Firms, 2004 to 2011. (a) Starbucks [56]. (b) Green Mountain Coffee Roasters [57]. (c) Equal Exchange [58].

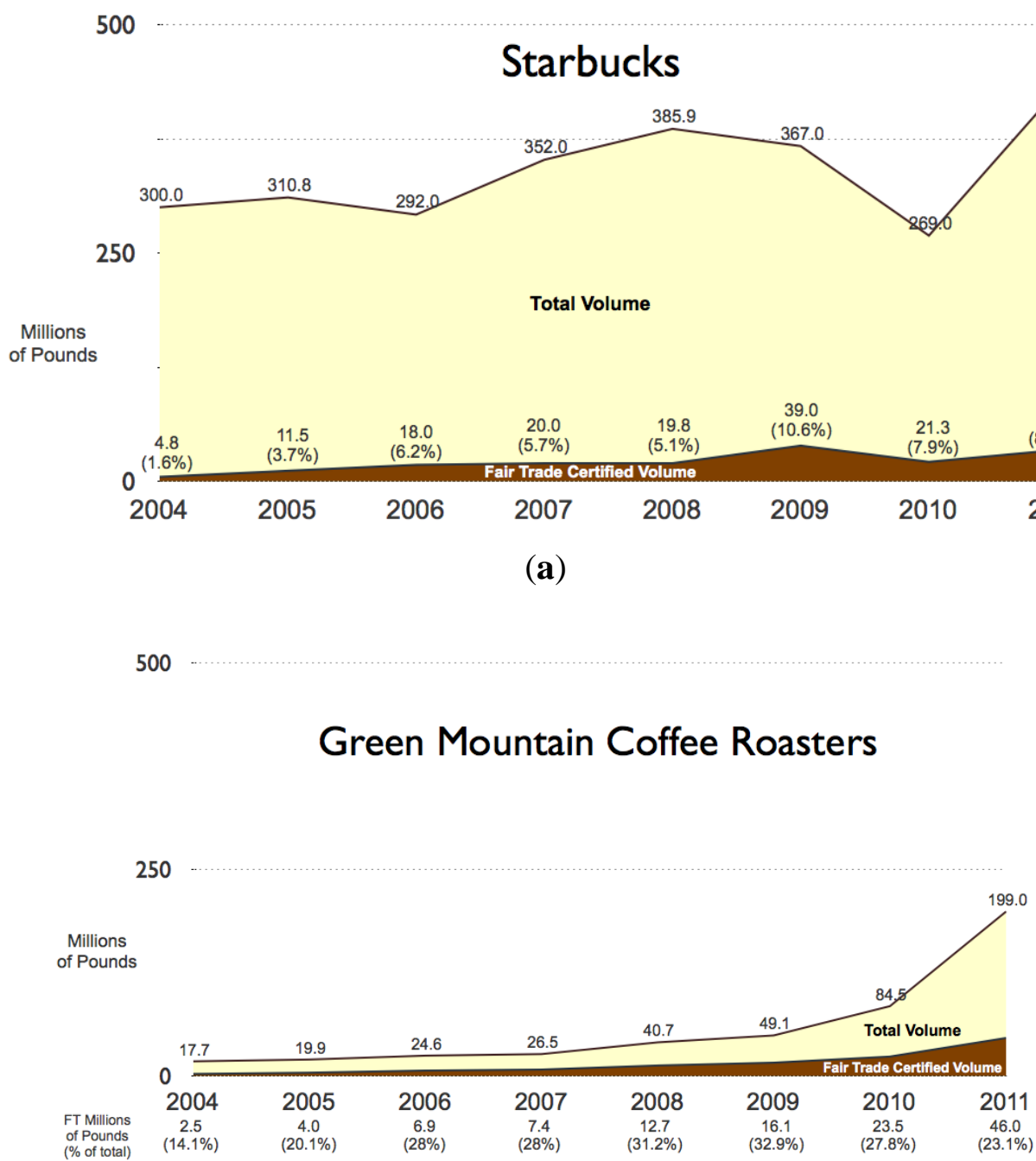

(b)

500

\section{Equal Exchange}

250

Millions
of Pounds

Total Volume (100\% Fairly Traded)

\begin{tabular}{|c|c|c|c|c|c|c|c|}
\hline 3.7 & 4.2 & 4.7 & 5.5 & 6.8 & 7.0 & 6.0 & 7.0 \\
\hline 2004 & 2005 & 2006 & 2007 & 2008 & 2009 & 2010 & 2011 \\
\hline
\end{tabular}

(c) 


\subsubsection{Commitment to Fair Trade Standards}

Each firm had a different response to Fair Trade USA's exit from the international fair trade system, and to its move to allow coffee from plantations to be certified as fair trade. These changes alter the social and economic aspects of sustainability that are captured by the fair trade label, which are given more prominence in both the standards and discourse of fair trade than its environmental aspects. FTUSA's actions required firms in the U.S. coffee industry to decide how to respond, and also generated a very public dialogue on the normative issues embedded in the firms' strategies.

Equal Exchange had the most dramatic reaction, announcing that it was abandoning FTUSA certification completely (the firm had already moved to alternative certifications such as IMO's Fair for Life for some of its products). Equal Exchange is currently purchasing coffee beans certified by Fair for Life, Fair Trade International (which is moving into the U.S. to compete with its former licensee FTUSA), and the Mexican nonprofit FUNDEPPO (which recently developed a Small Producers' Symbol).

Green Mountain Coffee Roasters has remained with FTUSA, and is currently sourcing coffee from one of their plantation pilot projects. Notably, the company has said it will not brand plantation coffee as fair trade "until we have evaluated the impact of these pilots at origin" [57]. Company representatives have emphasized that their measures of success include the potential impacts on sustainability, such as continuing to support small farmers. However, Larry Blanford, GMCR's president and CEO, signed a statement supporting the changes at Fair Trade USA.

Starbucks has also remained with FTUSA, but has not stated whether it will label plantation coffee as "fair trade". Ben Packard, the company's vice president for Global Responsibility, emphasized the market impacts, not sustainability goals, as a key driver of future decisions when he said, "We are waiting to see what the implications of these different schemes on the marketplace are going to mean" [11]. By "different schemes" he was also referring to Starbucks' first party C.A.F.E. Practices program, which, as mentioned above, is prioritized over fair trade in its marketing.

Equal Exchange eventually went even further than its initial response by encouraging GMCR and Starbucks to leave FTUSA certification and move to Fair Trade International's more rigorous seal. After meeting privately with GMCR executives in March, 2012 and failing to convince them of the strategy, Equal Exchange took the unusual move of placing a full-page color advertisement in Vermont's largest daily newspaper to repeat this request publicly [13]. The advertisement claimed that FTUSA's actions "threaten to reverse decades of hard-won gains while potentially putting at risk the very survival of the farmer cooperatives" [59]. Equal Exchange's Rodney North underscored the importance of this point, noting that "small farmer co-operatives were the co-creators of fair trade; to now take it and change it in a way that threatens their viability is unacceptable" [60]. Equal Exchange representatives described FTUSA's actions with respect to fair trade standards with words including "weaken," "loosen" "lower," "dilute," “undermine," and even "betrayal." While most of the firm's discourse focused on the impact the changes would have on small farmer cooperatives, it also mentioned the threat to consumer confidence in the FTUSA label. These points included that the change would make it impossible to distinguish between plantation and producer cooperative coffee, which ultimately may cause consumers to feel misled. 
GMCR and Starbucks have been much less visible in the media coverage surrounding Fair Trade USA's recent moves, but it is difficult to disentangle the perspectives of the certifier and these two corporations. In explaining the standards changes, Fair Trade USA's president and CEO, Paul Rice, has frequently referred to the needs of these and other large firms, such as Dunkin' Donuts and Whole Foods (owner of the Allegro coffee brand). He responded to suggestions that roasters at these corporations replace plantation coffee with smallholder-grown coffee in their blends as "the height of arrogance" because "no one tells them how to put together the perfect French roast [10]." Dean Cycon, owner of the small, mission-driven coffee firm Dean's Beans, said that Starbucks and Green Mountain would be able to become $100 \%$ fair trade certified under the new standards without changing "their business practices one iota [14]". Even Fair Trade USA's farmer cooperative assistance program (which was announced along with its decision to certify plantation coffee) is designed to help those cooperatives that are already some of the largest, and which supply GMCR and Starbucks [10].

Two arguments frequently used by both Fair Trade USA and GMCR representatives in support of the standards changes are: (1) they will increase the positive impacts of fair trade through higher volumes, and (2) expanding or extending the scheme to hired laborers who were previously "excluded" from fair trade will help the "poorest of the poor." GMCR coffee buyer Ed Canty, for example, asked, "Why can't these workers, who are some of the poorest of the poor, in some of these [coffee] estates be involved as well [12]?" Phyllis Robinson, Equal Exchange's education and campaign manager, responded to the first point, saying that, "To the extent that more volume equals more income (and more premiums), this is good for farmers. To the extent that more volume increases the visibility of fair trade for consumers, this is also a good thing... This issue however, isn't one of volume alone...we're talking about long-term structural change [61]." Equal Exchange's blog included a statement from Marike de Pena, vice president of the Latin American and Caribbean Network of Small Producer Organizations, who challenged the second point by claiming that "farmers' incomes are far below workers' income [62]."

GMCR has increased the visibility of fair trade, however, through a "Better Quality for All" marketing campaign, as well as a more recent, celebrity-driven campaign called "Great Coffee, Good Vibes, Pass It On." These campaigns emphasize how easy it is for consumers to participate in fair trade through a "simple purchasing decision" or a "simple choice." Equal Exchange representatives, in contrast, emphasize that consumer engagement in fair trade is far from simple, suggesting it is "time consuming" and "resource heavy," but that consumers need to "go further and learn more" and "get smarter and smarter."

Equal Exchange acknowledges not only the challenges for consumers, but the difficulty that increasing scale presents for their firm and for the industry. Marike de Pena, for example, who has experience competing with plantations in fair trade as a small-scale banana farmer, wrote on the Equal Exchange blog that "it is a lot easier, cheaper, faster and safer to buy from the big estates" [62]. Robinson echoes this point in several other Equal Exchange blog posts, stating that "working with small farmer organizations can be challenging and time consuming" and that "it may be a slower and less glamorous path to work with small farmer co-ops and consumers," but this approach is likely have a greater long-term impact on sustainability [61,63]. 


\section{Conclusions}

Equal Exchange, Green Mountain Coffee Roasters and Starbucks were identified as the three firms accounting for the highest proportion of fair trade coffee purchase in the U.S. These firms demonstrate an inverse relationship between firm size and commitment to sustainability ideals. Equal Exchange, the smallest firm, has maintained its historical commitment to $100 \%$ fair trade coffee purchases as it has grown to be the largest of the early entrants. The firm is also attempting to lead an exodus of roasters from Fair Trade USA, which it views as weakening the previous standards for coffee by allowing certification of plantations. Starbucks, the largest firm, has increased its volume commitment to fair trade over time, but with the exception of 2009 , this amount has not surpassed $8 \%$ of its total coffee purchases In addition, it has remained in the FTUSA system and has devoted few resources to raising the visibility of fair trade. GMCR is smaller than Starbucks, but recently replaced it as the world's largest purchaser of fair trade certified coffee, and this volume has approached one third of GMCR's total coffee purchases in some years. GMCR has, in contrast to Starbucks, devoted significant resources to promoting fair trade to consumers. On the other hand, the firm has also remained with FTUSA, and has offered only a mild critique of the certifier's recent policy shift by taking a "wait and see" approach on the inclusion of plantations.

While the greening of larger firms can potentially make an impact on industry sustainability more quickly than the growth of smaller, mission-driven firms, there are significant risks with this approach. In this study the larger, profit-driven firms demonstrated lower levels of commitment, a greater power to shape industry norms to their benefit, and less willingness to acknowledge tensions between size and sustainability. Although some studies suggest that large and small firms both have an important role to play in the transformation of industry toward sustainability [4,6], such a model underemphasizes the potential for co-optation [20], or for weakening standards so significantly that they eventually reduce consumer confidence in sustainability marketing as a whole [18].

These findings add to our understanding of sustainability in the fair trade coffee industry in the U.S., although their applicability to other sectors beyond coffee is somewhat limited by the nature of the case study; therefore we have primarily suggested hypotheses to be tested in other industries. The results indicate, however, that efforts to increase sustainability marketing for other products and services should take a more critical approach to pathways toward increasing industry sustainability that rely primarily on the participation of large, profit-driven firms. Attracting more smaller, mission-driven firms may be a slower approach, but may also be more likely to result in a deeply transformative effect on industry-wide sustainability efforts. Future research could identify cases of food ecolabels where barriers to the entry of large, profit-driven firms have been stronger (e.g., biodynamic, Animal Welfare Approved, and Certified Naturally Grown), and the impact that these have had on industry sustainability, as well as on consumer confidence in sustainability marketing in general.

\section{Conflict of Interest}

The authors declare no conflict of interest. 


\section{References}

1. Boström, M.; Klintman, M. Eco-Standards, Product Labelling and Green Consumerism; Palgrave Macmillan: Basingstoke, UK, 2008.

2. Howard, P.H.; Allen, P. Beyond organic and Fair Trade? An analysis of ecolabel preferences in the United States. Rural Sociol. 2010, 75, 244-269.

3. Raynolds, L.; Murray, D.; Heller, A. Regulating sustainability in the coffee sector: A comparative analysis of third-party environmental and social certification initiatives. Agric. Human Values 2007, 24, 147-163.

4. Hockerts, K.; Wüstenhagen, R. Greening Goliaths versus emerging Davids - Theorizing about the role of incumbents and new entrants in sustainable entrepreneurship. J. Bus. Venturing 2010, 25, 481-492.

5. Davies, I.; Doherty, B.; Knox, S. The rise and stall of a Fair Trade pioneer: The cafédirect story. J. Bus. Ethics 2010, 92, 127-147.

6. Schaltegger, S.; Wagner, M. Sustainable entrepreneurship and sustainability innovation: Categories and interactions. Bus. Strat. Environ. 2011, 20, 222-237.

7. Fridell, M.; Hudson, I.; Hudson, M. With friends like these: The corporate response to Fair Trade coffee. Rev. Radical Pol. Econ. 2008, 40, 8-34.

8. Howard, P.H. Consolidation in the North American organic food processing sector, 1997 to 2007. Int. J. Sociol. Agric. Food 2009, 16, 13-30.

9. Jaffee, D. Weak coffee: Certification and co-optation in the Fair Trade movement. Soc. Probl. 2012, 59, 94-116.

10. Sherman, S. The brawl over Fair Trade coffee. The Nation, 22 August 2012; Available online: http://www.thenation.com/article/169515/brawl-over-fair-trade-coffee (accessed on 5 October 2012).

11. Gram, D. Fair Trade purists cry foul at including big farms. The Associated Press, 31 May 2012.

12. Gram, D. Too much caffeine? Fair Trade coffees fighting. The Associated Press, 21 May 2012.

13. Chesto, J. Mass market; All is not mellow with Fair Trade coffee companies. The Patriot Ledger, 23 June 2012.

14. Neuman, W. A question of fairness. The New York Times, 24 November 2011, B1.

15. Doherty, B.; Davies, I.A.; Tranchell, S. Where now for fair trade? Bus. Hist. 2012, in press.

16. Reed, D. What do corporations have to do with Fair Trade? Positive and normative analysis from a value chain perspective. J. Bus. Ethics 2009, 86, 3-26.

17. Lyons, K. Supermarkets as organic retailers: Impacts for the Australian organic sector. In Supermarkets and Agri-Food Supply Chains: Transformations in the Production and Consumption of Foods; Burch, D., Lawrence, G., Eds.; Edward Elgar Publishing: Cheltenham, UK, 2007; pp. 154-172.

18. Gillespie, E. Stemming the tide of "greenwash". Consum. Policy Rev. 2008, 18, 79-83.

19. Jaffee, D. Brewing Justice: Fair Trade Coffee, Sustainability, and Survival; University of California Press: Berkeley, CA, USA, 2007.

20. Jaffee, D.; Howard, P. Corporate cooptation of organic and fair trade standards. Agric. Human Values 2010, 27, 387-399. 
21. Hatanaka, M.; Konefal, J.; Constance, D. A tripartite standards regime analysis of the contested development of a sustainable agriculture standard. Agric. Human Values 2012, 29, 65-78.

22. Templet, P.H. Grazing the commons: An empirical analysis of externalities, subsidies and sustainability. Ecol. Econ. 1995, 12, 141-159.

23. Dawson, M. The Consumer Trap: Big Business Marketing in American Life; University of Illinois Press: Champaign, IL, USA, 2003.

24. Pagell, M.; Wu, Z. Building a more complete theory of sustainable supply chain management using case studies of 10 exemplars. J. Supply Chain Manag. 2009, 45, 37-56.

25. Reardon, T.; Timmer, C.P.; Barrett, C.B.; Berdegué, J. The rise of supermarkets in Africa, Asia, and Latin America. Am. J. Agr. Econ. 2003, 85, 1140-1146.

26. Reardon, T.; Timmer, P.; Berdegue, J.A. The rapid rise of supermarkets in developing countries: Induced organizational, institutional, and technological change in agrifood systems. Electron. J. Agric. Dev. Econ. 2004, 1, 168-183.

27. Fridell, G. The co-operative and the corporation: Competing visions of the future of Fair Trade. J. Bus. Ethics 2009, 86, 81-95.

28. Haynes, J.; Cubbage, F.; Mercer, E.; Sills, E. The search for value and meaning in the cocoa supply chain in Costa Rica. Sustainability 2012, 4, 1466-1487.

29. Dougherty, D. Interpretive barriers to successful product innovation in large firms. Organ. Sci. 1992, 3, 179-202.

30. Dauvergne, P.; Lister, J. Big brand sustainability: Governance prospects and environmental limits. Global Environ. Change 2012, 22, 36-45.

31. Acs, Z.J.; Audretsch, D.B. Innovation, market structure, and firm size. Rev. Econ. Stat. 1987, 69, 567-574.

32. Lepoutre, J.; Heene, A. Investigating the impact of firm size on small business social responsibility: A critical review. J. Bus. Ethics 2006, 67, 257-273.

33. Bacon, C.M.; Méndez, V.E.; Fox, J.A. Cultivating Sustainable Coffee: Persistent paradoxes. In Confronting the Coffee Crisis: Fair Trade, Sustainable Livelihoods and Ecosystems in Mexico and Central America; Bacon, C.M., Méndez, V.E., Gliessman, S.R., Goodman, D., Fox, J.A., Eds.; MIT Press: Cambridge, MA, USA, 2008; pp. 337-372.

34. Fair Trade USA 2011 Almanac; Fair Trade USA: Oakland, CA, USA, 2012; pp. 1-61. Available online: http://fairtradeusa.org/sites/default/files/Almanac\%202011.pdf (accessed on 6 October 2012).

35. De Pelsmacker, P.; Driesen, L.; Rayp, G. Do consumers care about ethics? Willingness to pay for fair-trade coffee. J. Consum. Aff. 2005, 39, 363-385.

36. Arnot, C.; Boxall, P.C.; Cash, S.B. Do Ethical Consumers Care About Price? A Revealed Preference Analysis of Fair Trade Coffee Purchases. Canadian J. Agric. Econ./Rev. Canadienne d'Agroecon. 2006, 54, 555-565.

37. Didier, T.; Sirieix, L. Measuring consumer's willingness to pay for organic and Fair Trade products. Int. J. Consum. Stud. 2008, 32, 479-490.

38. Raynolds, L.T. Fair Trade: Social regulation in global food markets. J. Rural Stud. 2012, 28, $276-287$.

39. Renard, M.-C.; Pérez-Grovas, V. Fair Trade coffee in Mexico: At the center of the debates. In Fair Trade: The Challenges of Transforming Globalization; Raynolds, L.T., Murray, D., Wilkinson, J., Eds.; Routledge: New York, NY, USA, 2007; pp. 138-156. 
40. Besky, S. Can a plantation be fair? Paradoxes and possibilities in Fair Trade Darjeeling tea certification. Anthropol. Work Rev. 2008, 29, 1-9.

41. Neilson, J.; Pritchard, B. Fairness and ethicality in their place: the regional dynamics of fair trade and ethical sourcing agendas in the plantation districts of South India. Environ. Plann. A 2010, 42, 1833-1851.

42. Raynolds, L.T. Fair Trade flowers: Global certification, environmental sustainability, and labor standards. Rural Sociol. 2012, 77, 493-519.

43. Perfecto, I.; Vandermeer, J.; Mas, A.; Pinto, L.S. Biodiversity, yield, and shade coffee certification. Ecol. Econ. 2005, 54, 435-446.

44. Perfecto, I.; Armbrecht, I.; Philpott, S.M.; Soto-Pinto, L.; Dietsch, T.V. Shaded coffee and the stability of rainforest margins in northern Latin America. In Stability of Tropical Rainforest Margins; Tscharntke, T., Leuschner, C., Zeller, M., Guhardja, E., Bidin, A., Eds.; Environmental Science and Engineering; Springer: Berlin, Germany, 2007; pp. 225-261.

45. Méndez, V.E. Farmers' livelihoods and biodiversity conservation in a coffee landscape of El Salvador. In Confronting the Coffee Crisis: Fair Trade, Sustainable Livelihoods and Ecosystems in Mexico and Central America; Bacon, C.M., Méndez, V.E., Gliessman, S.R., Goodman, D., Fox, J.A., Eds.; MIT Press: Cambridge, MA, USA, 2008; pp. 207-236.

46. Raynolds, L.T. Mainstreaming Fair Trade coffee: From partnership to traceability. World Dev. 2009, 37, 1083-1093.

47. Ware, C. Information Visualization: Perception for Design, 2nd ed.; Morgan Kaufmann: San Francisco, CA, USA, 2004.

48. Howard, P.H. Visualizing consolidation in the global seed industry: 1996-2008. Sustainability 2009, 1, 1266-1287.

49. Coffee Barometer; Tropical Commodity Coalition: The Hague, Netherlands, 2009; pp 1-20.

50. Green Mountain Coffee Roasters Corporate Social Responsibility Report; Green Mountain Coffe Roasters: Waterbury, VT, USA, 2010; pp 1-68.

51. Starbucks Global Responsibility Report; Starbucks: Seattle, WA, USA, 2010; pp 1-15.

52. Fair Trade USA 2010 Almanac; Fair Trade USA: Oakland, CA, USA, 2010; pp 1-63.

53. Obermiller, C.; Burke, C.; Talbott, E.; Green, G.P. "Taste great or more fulfilling": The effect of brand reputation on consumer social responsibility advertising for Fair Trade coffee. Corp. Reputation Rev. 2009, 12, 159-176.

54. Grodnik, A.; Conroy, M.E. Fair Trade Coffee in the United States: Why Companies Join the Movement. In Fair Trade: The Challenges of Transforming Globalization; Raynolds, L.T., Murray, D., Wilkinson, J., Eds.; Routledge: New York, NY, USA, 2007; pp. 83-102.

55. Davies, I. Alliances and networks: Creating success in the UK Fair Trade market. J. Bus. Ethics 2009, 86, 109-126.

56. Starbucks Global Responsibility Report; Starbucks: Seattle, WA, USA, 2011; pp 1-22.

57. Green Mountain Coffee Roasters Corporate Social Responsibility Report; Green Mountain Coffee Roasters: Waterbury, VT, USA, 2011; pp 1-75.

58. Equal Exchange Annual Report; Equal Exchange: Bridgewater, MA, USA, 2011; pp 1-16.

59. An open letter to Green Mountain Coffee Roasters from Equal Exchange. 21 May 2012. Available online: http://www.equalexchange.coop/gmcr-ad.pdf (accessed on 6 October 2012). 
60. Hill, C. Fair Trade USA's coffee policy comes under fire. East Bay Express, 25 April 2012. Available online: http://www.eastbayexpress.com/ebx/fair-trade-usas-coffee-policy-comes-underfire/Content?oid=3184779 (accessed on 5 October 2012).

61. Robinson, P. Trying (but Failing) to Understand Arguments in Support of Fair Trade USA. Available online: http://smallfarmersbigchange.coop/2012/09/26/trying-but-failing-to-understandarguments-in-support-of-fair-trade-usa/ (accessed on 10 October 2012).

62. Robinson, P. Banana Producers from the Dominican Republic Say no to Plantations! Available online: http://smallfarmersbigchange.coop/2012/06/14/4866/ (accessed on 10 October 2012).

63. Robinson, P. Join with us to support authentic Fair Trade. Available online: http://smallfarmersbigchange.coop/2012/01/07/join-with-us-to-support-authentic-fair-trade/ (accessed on 10 October 2012).

(C) 2013 by the authors; licensee MDPI, Basel, Switzerland. This article is an open access article distributed under the terms and conditions of the Creative Commons Attribution license (http://creativecommons.org/licenses/by/3.0/). 